\title{
Listeria monocytogenes Biofilms in the Food Industry: Is the Current Hygiene Program Sufficient to Combat the Persistence of the Pathogen?
}

\author{
Tina Mazaheri, Brayan R. H. Cervantes-Huamán, Maria Bermúdez-Capdevila, Carolina Ripolles-Avila *D \\ and José Juan Rodríguez-Jerez (D)
}

Citation: Mazaheri, T.; Cervantes-Huamán, B.R.H.; Bermúdez-Capdevila, M.; Ripolles-Avila, C.; Rodríguez-Jerez, J.J. Listeria monocytogenes Biofilms in the Food Industry: Is the Current Hygiene Program Sufficient to Combat the Persistence of the Pathogen?. Microorganisms 2021, 9, 181. https://doi.org/10.3390/ microorganisms 9010181

Academic Editor:

Elena González-Fandos

Received: 22 December 2020

Accepted: 11 January 2021

Published: 15 January 2021

Publisher's Note: MDPI stays neutral with regard to jurisdictional claims in published maps and institutional affiliations.

Copyright: (c) 2021 by the authors. Licensee MDPI, Basel, Switzerland. This article is an open access article distributed under the terms and conditions of the Creative Commons Attribution (CC BY) license (https:/ / creativecommons.org/licenses/by/ $4.0 /)$.
Area of Human Nutrition and Food Science, Departament de Ciència Animal i dels Aliments, Facultat de Veterinària, Universitat Autònoma de Barcelona, 08193 Barcelona, Spain; tinamazaheri71@gmail.com (T.M.); brayancervanteshuaman@gmail.com (B.R.H.C.-H.); maria.bermudez@e-campus.uab.cat (M.B.-C.); josejuan.rodriguez@uab.cat (J.J.R.-J.)

* Correspondence: carolina.ripolles@uab.cat; Tel.: +34-935811448

\begin{abstract}
Biofilms contain microbial cells which are protected by a self-produced matrix and they firmly attach themselves to many different food industry surfaces. Due to this protection, microorganisms within biofilms are much more difficult to eradicate and therefore to control than suspended cells. A bacterium that tends to produce these structures and persist in food processing plants is Listeria monocytogenes. To this effect, many attempts have been made to develop control strategies to be applied in the food industry, although there seems to be no clear direction on how to manage the risk the bacteria poses. There is no standardized protocol that is applied equally to all food sectors, so the strategies for the control of this pathogen depend on the type of surface, the nature of the product, the conditions of the food industry environment, and indeed the budget. The food industry performs different preventive and corrective measures on possible L. monocytogenes-contaminated surfaces. However, a critical evaluation of the sanitization methods applied must be performed to discern whether the treatment can be effective in the long-term. This review will focus on currently used strategies to eliminate biofilms and control their formation in processing facilities in different food sectors (i.e., dairy, meat, fish, chilled vegetables, and ready-to-eat products). The technologies employed for their control will be exemplified and discussed with the objective of understanding how L. monocytogenes can be improved through food safety management systems.
\end{abstract}

Keywords: L. monocytogenes; food safety; biofilms; cleaning; disinfection

\section{Introduction}

Foodborne diseases occur due to the ingestion of food contaminated by biological or chemical agents, consequently causing social, economic, and public health problems [1,2]. In the latest report on the burden of foodborne diseases, it was estimated that 1 in 10 people in the world become ill after ingesting contaminated food and approximately 420,000 people die each year [3], a fact that requires the implementation of rigorous strategic prevention systems, control measures, and surveillance. For all these repercussions, which directly threaten public health and the world economy, it is important to invest in technologies that contribute to preventing foodborne diseases from occurring or to the early detection of threats in terms of food safety [4]. One of the most important prevention tools is the effective application of cleaning and disinfection methods to guarantee food safety [5]. In this regard, there is a high risk of contamination associated with a lack of procedures to ensure surfaces with a zero load of pathogenic microbiota, given the high probability that the product will come into contact with these areas during the handling process [6].

Among the most relevant pathogenic microorganisms at a European level, Listeria monocytogenes stands out for its high mortality rate of up to 15.6\% [7]. In recent years, 
a significantly increasing trend in the number of confirmed cases of L. monocytogenes in humans has been observed in the EU, up from 1883 confirmed cases in 2013 to 2549 in 2018, representing a notification rate of 0.47 cases per 100,000 inhabitants [7]. Furthermore, Dewey-Mattia et al. [8] indicate the relevance of this pathogen, since it is one of the etiologic agents most involved in hospitalizations and deaths in the USA. Therefore, the control of this pathogen has become one of the targets of greatest interest to the food industry [9].

Biofilms of L. monocytogenes on food contact surfaces have been identified as an important pathway for pathogenic persistence and subsequent product contamination [10-12]. To this effect, in-depth study of the nature, formation, detection, and elimination of biofilms on surfaces is of great importance due to their impact as a risk factor on outbreaks of foodborne diseases that affect public health $[13,14]$. The complex nature of biofilms and the capacity of the cells that make them up to strongly fix on surfaces that are difficult to access make the action of the disinfectants that are currently being applied less effective [5]. Another factor to consider is the ability of pathogenic microorganisms to generate resistance to current antimicrobial agents when cells form biofilms [15]. For all these reasons, it must be considered whether the current cleaning and disinfection procedures applied in food industries of different types are effective, or whether new methodologies or strategies are needed to solve the problem.

The objective of the present study was to determine, by means of a literature survey, whether the cleaning and disinfection systems applied nowadays in the food industry are effective for the elimination of L. monocytogenes biofilms. To do so, biofilm formation and their involvement in cross-contamination will be discussed to further evaluate the cleaning and disinfection treatments applied in different types of food industries.

\section{Importance of Cross-Contamination}

Over time, inadequate food handling or cooking procedures, breakage of the cold chain, and cross-contamination have been identified as the main drivers of foodborne illnesses [16]. Among these factors, cross-contamination has been highly involved in recent years, accounting for up to $91.7 \%$ of cases [17]. Microbial cross-contamination is the transfer of any microorganism from a contaminated biotic or abiotic matrix to an uncontaminated food product [18]. This contamination can happen during any stage of food processing, making the application of control and prevention systems with a global perspective crucial in the food industry [19]. While different raw and processed foods, such as inadequately pasteurized milk and ready-to-eat (RTE) products containing meat, eggs, and fish, have been identified as major sources of L. monocytogenes contamination [20], other food products have also been linked with the pathogen due to cross-contamination from industrial surfaces (Table 1 ). This is related to the ability of L. monocytogenes to adhere to and subsequently form biofilms on different food-processing equipment [21,22]. In this regard, equipment such slicing and grinder machines, cutting boards, knives, and tables have been identified as nutritive areas where the pathogen can easily grow due to being difficult to clean and disinfect [23]. Moreover, other industrial surfaces such as floors and sinks have been highlighted as potential focuses of this pathogen and as an initial route point for L. monocytogenes transfer to other surfaces [6]. It has been demonstrated that this foodborne pathogen can survive for long periods on industrial surfaces and can be transferred to food products, thus compromising its innocuity $[19,24]$. 
Table 1. Involvement of the environment and the industrial surfaces on the cross-contamination of food-products by Listeria monocytogenes.

\begin{tabular}{|c|c|c|c|c|}
\hline Implicated Food Product & Type of Industry & Country & Surface $^{x}$ & Reference \\
\hline Pasteurized milk cheese & $\begin{array}{l}\text { Cheese retailers and } \\
\text { cheese processing plant }\end{array}$ & Canada & $\begin{array}{l}\text { Knives, cutting boards, counters, } \\
\text { cheese plates, packers, } \\
\text { refrigerator handles, } \\
\text { brine solution }\end{array}$ & [25] \\
\hline $\begin{array}{l}\text { Raw and cooked meat of } \\
\text { blue crab }\end{array}$ & Meat processing plants & USA & $\begin{array}{l}\text { Floor drain, raw crab cooler, } \\
\text { receiving dock, gloves, table }\end{array}$ & [26] \\
\hline $\begin{array}{l}\text { Whole whitefish, whole } \\
\text { salmon and salmon fillet }\end{array}$ & $\begin{array}{l}\text { Smoked fish } \\
\text { processing plant }\end{array}$ & USA & $\begin{array}{l}\text { Floors, drains, cutting table, fork } \\
\text { truck bars, carts, coolers, trash } \\
\text { can, slicer }\end{array}$ & [26] \\
\hline Cantaloupe & $\begin{array}{l}\text { Cantaloupe farm and } \\
\text { processing plant }\end{array}$ & USA & $\begin{array}{c}\text { Cooler, truck, } \\
\text { downstream equipment }\end{array}$ & [27] \\
\hline Ice cream & Ice cream facilities & USA & Floor, drain & [28] \\
\hline $\begin{array}{l}\text { Pecorino Romano PDO and } \\
\text { ricotta salata cheese made } \\
\text { from pasteurized or } \\
\text { thermized sheep milk }\end{array}$ & $\begin{array}{l}\text { Sheep's cheese } \\
\text { making plants }\end{array}$ & Italy & $\begin{array}{l}\text { Molds, filters, floors, drains, } \\
\text { tables, conveyor belts, shelves, } \\
\text { washing machines }\end{array}$ & [29] \\
\hline $\begin{array}{l}\text { Ricotta salata made from } \\
\text { pasteurized sheep's milk }\end{array}$ & $\begin{array}{l}\text { Semi-finished cheeses } \\
\text { processing plant }\end{array}$ & Italy & $\begin{array}{l}\text { Washing machine's brush, } \\
\text { manhole, knife, cutting machine, } \\
\text { table, floor, trolley shelf }\end{array}$ & [30] \\
\hline $\begin{array}{c}\text { Raw pork pieces and minced } \\
\text { meat samples }\end{array}$ & Open meat markets & China & $\begin{array}{c}\text { Meat mincers, cutting tables and } \\
\text { weighing scales. }\end{array}$ & {$[31]$} \\
\hline Raw pork & Meat retail market & China & $\begin{array}{l}\text { Chopping boards and knives, } \\
\text { the inner and outer surfaces of } \\
\text { chest freezers, meat mincers, } \\
\text { hands of people, floors and walls }\end{array}$ & [32] \\
\hline Chilled roasted pork meat & Minced meat factory & Spain & Oven cart, larding needles & [33] \\
\hline $\begin{array}{l}\text { Plastic-packaged } \\
\text { RTE Meatballs }\end{array}$ & $\begin{array}{l}\text { RTE meat } \\
\text { production facility }\end{array}$ & Germany & $\begin{array}{l}\text { Conveyor belts, pulleys, freezers, } \\
\text { condensate lines or cable } \\
\text { ducts, gullies }\end{array}$ & [34] \\
\hline
\end{tabular}

${ }^{x}$ The type of material that surfaces were made of was included in the search but was not found in the studies analyzed.

Industrial surfaces, then, are important microbial reservoirs that need to be controlled to avoid cross-contamination. There are different determining factors that can influence this phenomenon, such as the fact that when surfaces are dry the risk of cross-contamination occurring is reduced since the growth and survivability of bacteria decreases. However, cross-contamination can be enhanced when surfaces are wet [35]. There are bacteria capable of withstanding prolonged dry conditions on surfaces [36]. Different studies show that there are pathogens that remain viable on dry stainless-steel surfaces for long periods of time, depending on different factors such as the characteristics of a microorganism, the levels of contamination, and its surrounding environment [37,38]. The persistence and resistance of pathogens such as L. monocytogenes to extreme environmental conditions is directly related to the ability of microorganisms to form biofilms [39].

\section{Biofilms}

Biofilms are defined as complex microbial communities, irreversibly attached to a biotic or abiotic surface and embedded in an extracellular component matrix (ECM) which exhibits an altered phenotype in relation to the rate of growth and gene transcription [40]. The ability of microorganisms to form biofilms is an adaptive and resistance strategy, which allows them to increase the availability of nutrients for their growth, facilitates the use of water, enables the transfer of genetic material, and what is most worrying for the 
food industry, gives them resistance to antimicrobial agents [5]. Consequently, routine cleaning and disinfection operations are often ineffective to remove and eliminate the microorganisms that make up these structures [41]. Furthermore, they have been shown to be more resistant to high temperatures, low $\mathrm{pH}$ [42], desiccation, UV rays, and salinity, thus increasing their difficulty to be controlled [43]. This resistance facilitates the persistence of the microbial cells that make up the biofilms on food contact surfaces and equipment, constituting a continuous source of contamination [44]. Hence, it is understandable how, according to the National Institute of Health (NIH) and the Center for Disease Control (CDC), biofilms are involved in more than $65 \%$ of foodborne diseases. It is therefore important that, to increase their effectiveness, cleaning and disinfection procedures are designed according to the type of problem that is detected.

\subsection{Initial Attachment and Development}

Biofilm formation is a dynamic process that takes place sequentially and includes five main stages. Initial adhesion is the first stage of the biofilm formation process, and is a reversible and weak type of adhesion where planktonic microbial cells adhere to a surface using physical forces and/or appendages such as pili, fimbria, or flagella [5]. The type of surface, the temperature, and the pressure can all modulate this adhesion phenomenon. The electrical charge of the cell surface, the Van der Waals forces, the hydrophobicity of the surface, the steric interactions, and electrostatic are also involved in this process [45]. At this stage, adhesion is reversible until the microorganisms differentiate by triggering morphological changes. Cells can still detach and return to planktonic form when they are in the reversible adhesion phase [46]. Different covalent and hydrophobic interactions occur [47] during irreversible adhesion, the second stage of the biofilm formation process, which is when the cells permanently adhere to each other and the surface [48]. Fixation occurs due to the action of different microbial appendages [49] and by ECM secretion [50]. In the third stage, the simultaneous production of ECM together with the accumulation and growth of attached microorganisms leads to the formation of microcolonies, where the bond between bacteria and the substrate is strengthened and the microbial colony stabilized [49]. Such accumulation stimulates the recruitment of planktonic cells from the surrounding environment through cell-to-cell communication, also named quorum sensing [48]. The fourth stage is when there is a mature biofilm due to the development of a highly organized ecosystem and a three-dimensional structure, which can be flat or mushroom-shaped [48]. During maturation, biofilms develop a rigid structure by means of the cellular production of extracellular polymeric substances (EPS) [51]. When using in vitro models to study pathogenic biofilms, it can take between seven [40] and ten days or more [46] to obtain structural maturity, depending on the microorganism and the environmental conditions established. Biofilm maturation is reached when these structures are crossed by water channels or pores, which ensure both the exchange of nutrients and metabolites and eliminate bacterial waste [5].

It has been indicated that when evaluating the effectivity of a cleaning and disinfecting treatment on biofilms it is preferable to use in vitro models that reproduce the structures in this mature stage as this is when they present most resistance and so the results can be more representative of the industrial reality [6,52]. Lastly, the fifth stage is related to dispersion, where sessile cells can return to their planktonic forms and transfer to the environment, once again able to colonize new surfaces [53]. Detachment may be due to low nutrient conditions as a survival mechanism and may be genetically determined. Dispersal is important for microorganisms to escape unfavorable habitats and generate new niches [54].

In the specific case of L. monocytogenes, flagella play a predominant role, at least in the early stages of biofilm formation. In this regard, temperature regulates flagellation of L. monocytogenes cells [55], so this is a factor that influences the process. The effect of temperature on L. monocytogenes biofilm formation has been extensively investigated, demonstrating that the pathogen is flagellated and motile at temperatures $\leq 30^{\circ} \mathrm{C}$, and 
generally not flagellated and not motile at temperatures above $30{ }^{\circ} \mathrm{C}$ [56]. Although flagellum-mediated attachment is a proven fact of initiation in biofilm formation [57], L. monocytogenes can adhere to inert surfaces through a process of passive independent binding of flagella [58]. Tresse et al. [59], have also reported a $\mathrm{pH}$ dependence for flagellation of L. monocytogenes and its consequences for cell adhesion. It has been shown that not all variables influence biofilm development to the same degree. For example, Poimenidou et al. [60], determined that the impact of nutrient availability on L. monocytogenes biofilm formation on stainless steel surfaces is greater than the influence of temperature. Once L. monocytogenes is irreversibly attached to the surface its cell mobility and autolytic capacity is reduced, a phenotypic variation that has been indicated to enhance the ability of this opportunistic pathogen to colonize environments [61].

\subsection{Extracellular Component Matrix (ECM)}

ECM is highly hydrated since it incorporates large amounts of water within its structure, reaching up to $97 \%$ of the whole biofilm matrix [49]. In most biofilms, the microbial count represents less than $10 \%$, while the matrix can represent more than $90 \%$ [62]. The ECM gives biofilms their mechanical stability, mediates their adhesion to surfaces, and forms a cohesive three-dimensional polymeric network that temporarily interconnects and immobilizes biofilm cells [63]. Due to the retention of extracellular enzymes, a versatile external digestive system is generated, sequestering dissolved nutrients from the aqueous phase and allowing them to be used as sources of nutrients and energy [5]. The matrix also acts as a recycling center, keeping all lysed cell components available. This includes DNA, which can represent a gene pool for horizontal gene transfer [63]. ECM can also serve as a source of nutrients, although some components of ECM are slowly biodegradable, and in fact complete degradation of all of their components requires a wide range of enzymes due to their complexity [64]. The matrix generally protects microorganisms against desiccation, oxidizing or charged biocides, some antibiotics, metal cations, and ultraviolet radiation [63]. Among the components that make up the ECM, there are mainly polysaccharides, proteins, and eDNA [13], in addition to various products from bacterial lysis in smaller quantities [65].

Polysaccharides are part of the extracellular matrix and perform various essential functions for the formation of biofilms, generally those associated with adhesion to surfaces and maintenance of structural integrity [66]. Furthermore, the proteins present in the extracellular matrix have functions that allow the growth of the biofilm and the survival of the housed cells through access to nutrients or the regulation of the integrity and stability of the biofilms. Proteins are involved in the formation and stabilization of the matrix polysaccharide network and constitute a link between the bacterial surface and the most glucidic components [67]. Lastly, the eDNA is also an integral part of the biofilm matrix. It acts as an intercellular connector, as a surface adhesive, or even as an antimicrobial, causing cell lysis by chelating lipopolysaccharide stabilizing cations and the bacterial outer membrane [68].

The matrix of L. monocytogenes biofilms is mainly composed of proteins $[40,69]$. In fact, treating biofilms of L. monocytogenes with proteases has been shown to damage the development of these structures or to cause cell dispersion [70]. Regarding its content in polysaccharides, Brauge et al. [71], demonstrate that Teichoic acids are the main components of the matrix. Colagiorgi et al. [62] demonstrate that eDNA is a relevant structural component in the L. monocytogenes matrix, where it cooperates with polysaccharides and proteins, guaranteeing the integrity of the biofilm [62]. Investigating the composition of these structures in macromolecules is of real importance since knowledge of them leads to the development of new alternative strategies for their elimination.

\subsection{Mechanisms of Resistance}

The resistance acquired by the cells that conform the biofilms is attributed to the properties associated with the biofilm, which include reduced diffusion, physiological 
changes due to reduced growth rates, and the production of enzymes that degrade antimicrobial substances [47]. It is difficult to establish a single mechanism as the cause of resistance as, in fact, this is given by a combination of many of them. There are studies where it has been observed that disinfectants such as peracetic acid, mercuric chloride, and formaldehyde have been shown to have no effect on certain microorganisms when they are in the form of biofilms [47]. The explanation for the reduced efficacy of these agents against these communities is the incomplete penetration of the biocides through the matrix. It has also been determined that exposure of microorganisms to subinhibitory concentrations of quaternary ammonium compounds (QAC), which can happen when they are in a biofilm form, can lead to the selection of resistant microorganisms that can survive subsequent disinfection treatments applied with higher concentrations of the same compounds [15,72]. To this effect, Chambless et al. [73] propose four possible mechanisms of resistance to biocidal agents of the cells present in the biofilms: (i) difficulty of biocides to penetrate into external areas of the biofilm; (ii) generation of a stress response by some microorganisms; (iii) alteration of the biofilm environment in response; and (iv) microbial resistance by phenotypic differentiation.

In the case of L. monocytogenes, it has been determined that the persistence of certain strains, even after cleaning and disinfection, may be related to subinhibitory exposure to disinfectants. This phenomenon can be explained not only by the acquisition of resistance mechanisms by L. monocytogenes, but also by the existence of niches or reservoirs in the environment not reached by disinfectants, and by the formation of biofilms and the consequent creation of protected microenvironments [15]. For example, genotypic resistance to QAC by this pathogen has been described. Multiple reflux pumps have been characterized that confer some resistance to QACs. However, as previously commented, the dilution or inactivation of QACs in the environment due to an erroneous cleaning and disinfection protocol also has an influence. This resistance to QAC can end up contributing to its adaptation and environmental persistence [74].

\section{Listeria monocytogenes}

\subsection{Generalities and Characteristics}

L. monocytogenes is a ubiquitous bacterium which has been isolated from soil, plants, silage, and water, particularly from food processing environments and especially in refrigerated premises, despite them being routinely cleaned and disinfected [75], hence, they are responsible for numerous food outbreaks [76]. The pathogen is also a transitory resident of the intestinal tract in humans, with $2-10 \%$ of the general population carrying the microorganism with no apparent health consequences [77]. Its entry into food processing plants can occur through many different routes, from raw materials to contact with contaminated surfaces on equipment or generally in the facilities [23].

L. monocytogenes is a rod-shaped, Gram-positive, catalase positive, facultative anaerobic, non-sporulating, psychotrophic mesophilic pathogen [78]. Its ability to survive temperatures between -0.4 to $50^{\circ} \mathrm{C}, \mathrm{pH}$ from $4.6-9.5$, low water activity up to 0.92 , and high concentrations of salt (10-2\%) and sugar $(39.4 \%$ sucrose) $[79,80]$, contribute to its persistence in food processing environments, which implies a permanent risk of crosscontamination of products [81].

Up to now, at least 13 distinct $L$. monocytogenes serotypes have been identified, although only serotypes $1 / 2 a, 1 / 2 b, 1 / 2 c$ and $4 b$ have been involved in $98 \%$ of human listeriosis cases worldwide [82]. These 13 serotypes are grouped into 4 different lineages (I, II, III and IV), defined using molecular typing methods such as pulsed field gel electrophoresis (PFGE) [83]. It has been observed that different serotypes can generate different population structures and may have different abilities to combat environmental stress [84]. Regarding incidence, the majority of listeriosis cases are caused by L. monocytogenes strains belonging to serotypes $1 / 2 \mathrm{a}, 1 / 2 \mathrm{~b}$, and $4 \mathrm{~b}$, and to a lesser extent, $1 / 2 \mathrm{c}$. Interestingly, isolates of serotype $1 / 2$ a are highly prevalent in food processing settings, compared to isolates of serotype $4 b$ [85]. 


\subsection{Recent Food-Related Crises}

L. monocytogenes causes a foodborne illness named listeriosis, which primarily affects pregnant women, neonates, the elderly, and immunocompromised individuals [86]. Although L. monocytogenes is responsible for only $1 \%$ of foodborne illness, its mortality rate is high, far exceeding that of other foodborne pathogens [87]. The first listeriosis food crisis occurred in Canada and was associated with the consumption of contaminated cabbage salad [88]. Since then, there have been various food crises related to this foodborne pathogen, standing out among them the largest listeriosis outbreak ever documented, which occurred in South Africa. Between January 2017 and May 2018, there were 1034 laboratory-confirmed cases of listeriosis, more than 400 (42\%) cases in newborns, and 204 associated deaths. The case-fatality rate in South Africa was estimated at $28.6 \%$ and was comparable to other reported outbreaks of listeriosis worldwide [89]. In 2018, 2549 confirmed cases of listeriosis in humans were reported in the EU. There has been a statistically significant upward trend in confirmed cases of listeriosis in the EU for the period 2012-2018, with a case fatality in the EU of $15.6 \%$ [7]. Focusing on the crises caused by this pathogen in the EU in recent years, in 2018 an outbreak of listeriosis in a Hungarian factory was reported, linked to the production of frozen vegetables and affecting seven countries and a total of 47 people. This factory produced and exported to more than 100 countries [90]. Consequently, European Food Safety Authority (EFSA) recently published an evaluation of the risk posed by L. monocytogenes during the processing of frozen fruits and vegetables to enhance its control and avoid subsequent crises [91]. Furthermore, the pathogen has been highly related to processed meat outbreaks [92]. On this regard, in August 2019, the most important listeriosis outbreak in the history of Spain was recorded, affecting over 200 people, of whom three died and five cases resulted in miscarriages [33].

\subsection{L. monocytogenes and Its Affinity for Materials}

L. monocytogenes has the ability to adhere to and from biofilms on industrial surfaces, especially where food residues accumulate [93]. As previously discussed, this is a mechanism of potential resistance to antimicrobial agents, biocides, and heat [94]. The resistance of bound bacteria to biocides has been mainly associated with mechanical protection due to the synthesis of ECM and the surrounding nutrients, or with intrinsic physiological factors such as the adaptation of biofilm cells to stresses like acid, oxidative stress, and starvation, among many others [95]. A series of studies on materials commonly used in food facilities and premises have demonstrated the presence of L. monocytogenes [23], showing its capacity to adhere to and develop on polystyrene as a material employed to construct drains [96]; polytetrafluoroethylene (PTFE) used in conveyor belts [97]; stainless steel used for the majority of the equipment employed in the food industry [6]; polyester used as a floor sealer [98]; and rubber used in joints and glass [99], or glass and Teflon [100]. However, the degree to which $L$. monocytogenes adheres to these materials differs depending on each type.

\section{Control Strategies Implemented in the Food Industry}

Cleaning and disinfection are an essential part of the Hazard Analysis and Critical Control Points (HACCP) system. Auditing is also an important factor, guaranteeing a reduction in the risk and increasing food safety to provide a safe environment for the manufactured food products in the food industry [101,102]. Sanitation programs have a different objective in food processing environments, among which the following stand out: the removal of visible soil (i.e., organic or inorganic) and allergens, which would be detrimental to the safety or organoleptic quality of subsequent production runs; and the elimination of microorganisms that may cause an alteration of the organoleptic characteristics or can pose a risk to public health [102].

\subsection{Cleaning}

In food processing industries, cleaning is based on the removal of residues and harmful microorganisms such as L. monocytogenes to protect food from contamination from surfaces, 
employing physical or chemical methods $[103,104]$. Another objective of the cleaning program is to ensure a clean environment for employees, and to prepare equipment and other industrial surfaces in the food area which are difficult to clean, with the aim of extending the product shelf-life and preventing future damage $[105,106]$. Effective cleaning must break or damage extracellular matrices of biofilms, so that later disinfectants can access the microbial viable cells [107]. Cleaning programs are defined according to the type of dirt present and the type of food processing environment produced. This operation is carried out by applying detergents, which are selected based on the type of product being processed, the type of residue it generates, and the physic-chemical properties of the surfaces being cleaned [108]. Knowing the type of dirt to be removed allows products, systems, and conditions to be chosen to optimize cleaning processes. Cleaning products must have three important characteristics: chelating power, a degreaser, and a dispersant. The first refers to the ability to sequester minerals, preventing them from crystallizing, precipitating, and embedding in the materials on which it is being applied. The second relates to the ability to emulsify and disperse fats, and the third is the ability to break down dirt particles and keep them in suspension [109]. During the cleaning process, a proportion of the microorganisms present can be detached from food contact surfaces. However, some can be non-detached and if water and nutrients are present, during a period of time some microorganisms can adhere to the other surfaces to re-start the cycle of biofilm production. Subsequent disinfection must therefore be applied to remove all foodborne pathogens [110].

\subsection{Disinfection}

Disinfection is the procedure to eliminate the microorganisms completely or to reduce their number to an acceptable level using antimicrobial products, chemical agents, or thermal methodologies [111,112]. This is an important step in the sanitization process as the presence of foodborne pathogens such as L. monocytogenes in food industries can be extremely harmful for public health $[75,113]$. Therefore, L. monocytogenes biofilms adhered in processing plants possess increased resistance to environmental conditions, making their removal more difficult [114]. For this reason, selecting the composition of a disinfectant, particularly the active biocidal substance or a combination of several of them, is also dependent on the extracellular matrix component of biofilms. For example, QACs such as benzalkonium chloride are cationic surfactants that act by disrupting lipid membrane bilayers and are effective against a number of pathogenic microorganisms, especially Gram-positive bacteria [115].

\subsection{Complementary Alternative Strategies}

The development of sanitation processes is looking towards alternatives that do not enhance resistance or towards strategies that prevent irreversible adhesion to surfaces and the subsequent development of mature biofilms. The growing negative perception of consumers regarding chemical substances has pushed research towards different environmentally friendly alternatives [116]. Among these are enzymes, bacteriophages, quorum sensing inhibitors, essential oils, and others [117]. Enzymatic technology allows for a high degree of personalization in surface sanitization, and so depending on the composition of the biofilm matrix formed by the predominant microorganisms on the surfaces, specific strategies can be defined to optimize their effectiveness. However, its use must be optimized due to its high cost, which is achieved by adjusting the optimal temperature and $\mathrm{pH}$ conditions [118]. This allows the concentration of the enzymes to be reduced to a minimum, thus maintaining their effectiveness. In the case of bacteriophages, their antimicrobial action is specific against prokaryotic cells and harmless to humans, animals, and plants [117]. However, other authors disagree on its total safety [119]. The main limitation of phage treatments is their ability to access and attack bacterial cells within the biofilm due to its structure, which acts as a physical obstacle. However, some phages possess depolymerases, which improve the phage invasion and dispersion process 
through the biofilm under treatment [120]. Quorum sensing is a mechanism for regulating gene expression in response to cell population density. In biofilms, it regulates population density and all metabolic activity. This achieves better adaptation to the environment and greater resistance in hostile environments and disinfection processes [121]. Its inhibition is therefore a preventive strategy focused on interrupting biofilm formation by controlling the stages of microbial microcolony formation [122,123]. Essential oils are generally recognized as safe by the US Food and Drug Administration (FDA). Several studies have shown that they have strong antimicrobial and anti-biofilm activity against a variety of microorganisms [124-126]. Lastly, another interesting approach to the microbiological control of surfaces is the use of microorganisms that may have the ability to compete with foodborne pathogens and thereby prevent their growth [6]. Even more interesting is the use of microbial species belonging to the resident microbiota of the food industries, which is not only an interesting ecological alternative to explore, but also opens up a field of study with great future prospects [127].

In the specific case of biofilms formed by L. monocytogenes, various investigations have been carried out on complementary alternative strategies for their control. It is known that the composition of a biofilm formed by L. monocytogenes is mostly protein [62], which is why protease treatments have been used on surfaces and have been shown to trigger an alteration in the development of biofilms [128]. An example of a bacteriophage used is Listeria phage P100, which was produced to eliminate biofilms present in processed meat products and on food contact surfaces in processing industries [129]. Gao et al. [130] have investigated the anti-biofilm efficacy of Fingered Citron essential oil (FCEO) against L. monocytogenes. In this study, FCEO was found to exhibit strong anti-biofilm activity, inhibiting biofilm formation, eradicating preformed biofilm, and also causing cell death. Further studies are needed to determine the viability of L. monocytogenes in industrial conditions.

\subsection{L. monocytogenes in the Food Industry: Its Control}

\subsubsection{Dairy Industry}

The presence of $L$. monocytogenes in this type of industry is highly relevant given that the pathogen is able to grow at refrigeration temperature and there are certain processing steps that imply the use of low temperatures to preserve raw materials or processed ones, such as when milk is stored in tanks $\left(4^{\circ} \mathrm{C}\right)$. The risk of contaminating dairy products such as cheese by L. monocytogenes is directly related to transfer from farm to dairy animals, unhygienic processes, poor pasteurization, and cross-contamination after heat treatment [131]. Within the dairy industry, cheese is considered one of the products most frequently contaminated with L. monocytogenes [132]. According to Ramaswamy et al. [133], blue-veined and molded cheeses like Brie, Camembert, Danish Blue, Stilton, and Gorgonzola possess highly nutritive sources and constitute a perfect environment for the growth of this pathogen. Different studies to control L. monocytogenes such as Ultra HighPressure Homogenization (UHPH), pressurized jet water [134], ozone [135], and infrared light [136], have demonstrated that, in Gorgonzola rinds, these technologies are effective in reducing L. monocytogenes levels by up to $2-3 \log$. Treating these type of products with antimicrobials produced by lactic acid bacteria (LAB) or some yeasts such as bacteriocins, ethanol, and other organic acid has been proposed to prevent $L$. monocytogenes growth if cross-contamination of cheeses occurs [137]. In this regard, LAB can be considered a non-chemical alternative in dairy products.

Furthermore, a recent study conducted by Ripolles-Avila et al. [40] shows that L. monocytogenes takes seven days to form highly mature biofilms on industrial surfaces when a constant nutrient source is present in the system. This is why a cleaning program is supposed to remove most of the organic matter in food industry areas and the cleaning program should also focus on floors, walls, milking equipment, and difficult to clean areas [138]. A well implemented cleaning program can help to displace milk deposits, dissolve milk proteins, emulsify fat, and aid the removal of dirt. In Guerrero-Navarro 
et al. [103], two commercial agents were used, one with chemical components and another which was based on a biological solution, the use of enzymes. The results showed that in the dairy industry, enzymatic cleaning agents obtained better results in terms of eliminating organic matter than chemical agents. In this regard, enzymatic products are eco-friendly, therefore not harmful to the environment, and help to reduce wastewater in dairy factories [139].

\subsubsection{Meat Processing Industry}

In the meat industry, raw meat and RTE products are considered an important vehicle for L. monocytogenes transmission $[140,141]$. In addition to water and handlers, industrial surfaces are an important factor to control and prevent the cross-contamination of meat by L. monocytogenes [142]. As has been indicated, for the control of cross-contamination, the most important action is the cleaning and disinfection procedures of industrial surfaces. In this regard, Mazaheri et al. [64] indicate that enzymatic cleaning treatments could remove mature L. monocytogenes isolated from stainless steel surfaces in an Iberian pig processing plant with an effectivity of $85-99 \%$. In the same line, Ripolles-Avila et al. [52] compare the effectivity of enzymatic treatment and chlorinated alkaline treatment for the elimination of mature L. monocytogenes biofilms from strains also isolated from the meat industry. The results showed a significantly higher effectivity of the enzymatic treatment, demonstrating that the inclusion of new perspectives is needed to combat these structures in the food industry.

Furthermore, some authors have begun to indicate that the total elimination of microorganisms present on industrial surfaces may not always be of interest. For example, in meat products such as certain fermented sausages, it may be desirable that LAB such as Lactobacillus spp. and Leuconostoc spp. remain on the surfaces to improve and facilitate the fermentation process [74]. In a recent study, Ripolles-Avila et al. [6] observe that the complete elimination or a great reduction of the resident microbiota from the surfaces can enhance the growth of pathogens such as L. monocytogenes. This may be because this pathogen is a poor competitor and microorganisms such as LAB or aerobic mesophilic may impede its growth [127]. It may also be due to the production of L. monocytogenes inhibitory substances by the resident microbiota. In addition, there are authors who demonstrate an interrelation between microorganisms of different species and pathogens such as L. monocytogenes, forming multispecies biofilms [6,143].

\subsubsection{Fish Processing Industry}

Fish is another of the foods susceptible to L. monocytogenes contamination [144]. The microbial contamination of fish and seafood usually happens naturally from the environment during harvesting or occurs during handling and manufacturing in industry $[145,146]$. Most foodborne pathogens are not able to grow below $10^{\circ} \mathrm{C}$, and the few that do will not grow under $4^{\circ} \mathrm{C}$. Hence the risk of contamination in frozen fish is not extreme [147]. However, different microorganisms such as Aeromonas spp., Plesiomonas spp., Clostridium botulinum, L. monocytogenes and Vibrio spp. are mainly responsible for fish product spoilage or pathogenicity and can survive at chill temperatures $[147,148]$.

The foodborne pathogen L. monocytogenes is ubiquitous and has been found in natural environments such as water or food processing environments, hence it can enter into contact with fish or fish products [74]. Distinct products have been identified as potential sources of L. monocytogenes exposure to humans [149]. One of the products most involved is smoked salmon [149]. Research on sanitization in fish factories has been carried out to optimize treatments and increase effectivity. According to Holck et al. [149] and Mcleod et al. [150], UV light could be an alternative for surface decontamination given that it causes microbial inactivation through DNA damage. Chlorine and the products that produce chlorine include hydrogen peroxide and quaternary ammonium compound, two of the disinfectants commonly used in seafood plants [151,152]. A recent study by Lasagabaster et al. [153] proposes the use of bacteriophage as a green strategy to eliminate L. monocytogenes biofilms 
from processing equipment, thus improving seafood safety. Sadekuzzaman et al. [154] explore treating L. monocytogenes with bacteriophage reduced biofilm cells on stainless-steel surfaces and rubber surfaces.

\subsubsection{Chilled Vegetable Industry}

As part of the modern lifestyle, consumers search for healthier, easier to prepare food to reduce preparation time. One of these products is frozen vegetables [155]. As previously indicated, L. monocytogenes is a psychotropic bacterium that can grow at refrigeration temperatures and can be present in frozen vegetables [80]. According to EFSA [91], in the EU (2015-2018) there was an outbreak of L. monocytogenes ST6 related to blanched frozen vegetables in several countries. Evidence of foodborne outbreaks shows that $L$. monocytogenes is the most relevant pathogen associated with this type of product.

The food industry commonly uses chlorine compounds such as chlorhexidine and benzalkonium chloride as disinfectants. However, the resistance of some L. monocytogenes isolates to these compounds has been described by Soumet et al. [156]. To this effect, Popowska et al. [157] analyze a total of 96 identified L. monocytogenes strains of frozen foods and dairy products, with the aim of determining their susceptibility to benzalkonium chloride and chlorhexidine. In the case of benzalkonium chloride, $16 \%$ of the strains were characterized by a reduced susceptibility of 2 to 4 times. For chlorhexidine, however, $82 \%$ of the studied strains had a reduced susceptibility to the disinfectant of 2 to 4 times. Furthermore, Godinez-Oviedo et al. [158] characterize L. monocytogenes strains isolated from a frozen vegetable processing plant to determine the pathways of contamination of the pathogen. It was determined that the pathogen persistence spaces correspond mainly to those with contact with food, which therefore become an important source of cross contamination.

\subsubsection{Ready-to-Eat (RTE) Products Industry}

According to previous study by the FDA and the Food Safety and Inspection Service (FSIS) [159] and Pouillot et al. [160], some of the physical and chemical characteristics of RTE such as $\mathrm{pH}$ and water activity create a suitable environment for L. monocytogenes growth. In this regard, Cossu et al. [161] show that an RTE sandwich factory had a high rate of contamination by L. monocytogenes. In this regard, the addition of some of the antimicrobial substances mentioned before could prevent L. monocytogenes growth [162]. For example, some combination acidic substances such as sorbic acid and benzenic acid could prevent the growth L. monocytogenes in deli-type salads [163-165]. The formulation of RTE products including a combination of natural antimicrobial substances has been demonstrated to be effective against $L$. monocytogenes growth during the shelf-life of these products [166].

Control of L. monocytogenes in RTE meat products, especially high-risk ones such as hot dogs and deli meats, is based on the use of intensive programs of environmental sanitation, thermal processing such as cooking or pasteurizing in the package, and the incorporation of antimicrobial agents as part of the ingredient formulation (i.e., nitrites, acetates, citrates, diacetates, lactates, and propionates) and sometimes as surface sprays (i.e., lauric arginate and essential oils). The irradiation of RTE products has been widely explored, and the technology has been considered by the FDA to be safe for use in meat and poultry. High hydrostatic pressure has also been evaluated for the control of L. monocytogenes in RTE meats with promising safety results, although quality parameters remain compromised. There is also biocontrol, which refers to the use of natural or controlled microorganisms or their antimicrobial products to extend the shelf life or improve the microbiological safety of food. In food, biocontrol is generally carried out by two groups of biological agents: bacteriophages or viruses that specifically infect bacteria and LAB [167]. The Smoked Seafood Working Group (SSWG) has developed guidelines to minimize L. monocytogenes contamination of smoked seafood products. The SSWG have identified 5 elements required for a complete Listeria spp. control program, namely Listeria specific Good Manufacturing 
Practices and sanitation procedures, employee training, environmental microbiological monitoring and testing, raw material controls, and temperature controls for finished products [168]. Furthermore, Valenzuela-Martinez et al. [169] evaluate the use of vinegar against $L$. monocytogenes in RTE and poultry products stored at $4{ }^{\circ} \mathrm{C}$. The results showed that the vinegar-treated samples resulted in a growth of $<1 \log \mathrm{CFU} / \mathrm{g}$ over the shelf life (120 days). This research provides an alternative to guarantee the food safety of RTE meat products.

\section{Conclusions}

Controlling L. monocytogenes at levels that avoid food contamination requires intense efforts, in addition to the application of new technologies as complementary strategies. The most successful hygiene programs for L. monocytogenes control are not based on a single type of treatment, whether physical or chemical, but on the combination of the two. Additionally, the inclusion of complementary alternative strategies has been shown to provide interesting results for the control of this pathogen, although more industrial studies are required to verify if they are feasible to apply in industrial environments. In general, the way to control L. monocytogenes in food plant environments is to reduce or eliminate the risk of recontamination because of the presence of biofilms in industrial surfaces. Therefore, each and every possible contamination vector must be identified, and control measures implemented to eliminate L. monocytogenes at each entry point, including the drains, floors, processing equipment, walls, floors, ceilings, refrigeration units, and air/particle sources. A vision directed at the type of industry in conjunction with the use of conventional and alternative treatments aimed at attacking both the majority residues and the dominant microbiota can help to better control L. monocytogenes in the food industry.

Author Contributions: Conceptualization, T.M., C.R.-A. and J.J.R.-J.; methodology, T.M., B.R.H.C.-H. and M.B.-C.; investigation, T.M., B.R.H.C.-H., M.B.-C. and C.R.-A.; resources, J.J.R.-J.; writing-original draft preparation, T.M., B.R.H.C.-H. and M.B.-C.; writing-review and editing, C.R.-A. and J.J.R.-J.; supervision, C.R.-A. and J.J.R.-J.; project administration, C.R.-A. and J.J.R.-J.; funding acquisition, J.J.R.-J. All authors have read and agreed to the published version of the manuscript.

Funding: This study was supported by Research Project grants RTI2018-098267-R-C32 from the Ministerio de Ciencia, Innovación y Universidades.

Institutional Review Board Statement: Not applicable.

Informed Consent Statement: Not applicable.

Data Availability Statement: Not applicable.

Acknowledgments: The authors thank Dolors Busquets Soler for her technical assistance in the laboratory and Sarah Davies for the English grammar review.

Conflicts of Interest: The authors declare no conflict of interest.

\section{References}

1. Food Safety/WHO. Available online: https://www.who.int/news-room/fact-sheets/detail/food-safety (accessed on 23 November 2020).

2. Espinosa, L.; Varela, C.; Martínez, E.V.; Cano, R. Brotes de enfermedades transmitidas por alimentos. España, $2008-2011$ (excluye brotes hídricos). Boletín Epidemiológico Semanal 2014, 22, 130-136.

3. World Health Organization. WHO Estimates of the Global Burden of Foodborne Diseases Short; Tech. Rep.; World Health Organization: Geneva, Switzerland, 2015; pp. 1-255. [CrossRef]

4. Hoelzer, K.; Moreno Switt, A.I.; Wiedmann, M.; Boor, K.J. Emerging needs and opportunities in foodborne disease detection and prevention: From tools to people. Food Microbiol. 2018, 75, 65-71. [CrossRef] [PubMed]

5. González-Rivas, F.; Ripolles-Avila, C.; Fontecha-Umaña, F.; Ríos-Castillo, A.G.; Rodríguez-Jerez, J.J. Biofilms in the spotlight: Detection, quantification, and removal methods. Compr. Rev. Food Sci. Food Saf. 2018, 17, 1261-1276. [CrossRef] [PubMed]

6. Ripolles-Avila, C.; Hascoët, A.S.; Martínez-Suárez, J.V.; Capita, R.; Rodríguez-Jerez, J.J. Evaluation of the microbiological contamination of food processing environments through implementing surface sensors in an iberian pork processing plant: An approach towards the control of Listeria monocytogenes. Food Control 2019, 99, 40-47. [CrossRef]

7. EFSA-ECDC. The European Union One Health 2018 Zoonoses Report. EFSA J. 2019, 17, 1-276. [CrossRef] 
8. Dewey-Mattia, D.; Manikonda, K.; Wise, M.E.; Crowe, S.J. Surveillance for foodborne disease outbreaks-United States, 2009-2015. MMWR Surveill. Summ. 2018, 67, 1-11. [CrossRef]

9. Silva, D.A.L.; Botelho, C.V.; Martins, B.T.F.; Tavares, R.M.; Camargo, A.C.; Yamatogi, R.S.; Bersot, L.S.; Nero, L.A. Listeria monocytogenes from farm to fork in a Brazilian pork production chain. J. Food Prot. 2020, 83, 485-490. [CrossRef] [PubMed]

10. Nowak, J.; Cruz, C.D.; Tempelaars, M.; Abee, T.; van Vliet, A.H.M.; Fletcher, G.C.; Hedderley, D.; Palmer, J.; Flint, S. Persistent Listeria monocytogenes strains isolated from mussel production facilities form more biofilm but are not linked to specific genetic markers. Int. J. Food Microbiol. 2017, 256, 45-53. [CrossRef]

11. Pažin, V.; Jankuloski, D.; Kozačinski, L.; Dobranić, V.; Njari, B.; Cvrtila, Ž.; Lorenzo, J.M.; Zdolec, N. Tracing of Listeria monocytogenes contamination routes in fermented sausage production chain by pulsed-field gel electrophoresis typing. Foods 2018, 7, 198. [CrossRef]

12. Rodríguez-Campos, D.; Rodríguez-Melcón, C.; Alonso-Calleja, C.; Capita, R. Persistent Listeria monocytogenes isolates from a poultry-processing facility form more biofilm but do not have a greater resistance to disinfectants than sporadic strains. Pathogens 2019, 8, 250. [CrossRef]

13. Jahid, I.K.; Ha, S. A review of microbial biofilms of produce: Future challenge to food safety. Food Sci. Biotechnol. 2012, 21, 299-316. [CrossRef]

14. Ripolles-Avila, C.; Ríos-Castillo, A.G.; Rodríguez-Jerez, J.J. Development of a peroxide biodetector for a direct detection of biofilms produced by catalase-positive bacteria on food-contact surfaces. CYTA J. Food 2018, 16, 506-515. [CrossRef]

15. Martínez-Suárez, J.V.; Ortiz, S.; López-Alonso, V. Potential impact of the resistance to quaternary ammonium disinfectants on the persistence of Listeria monocytogenes in food processing environments. Front. Microbiol. 2016, 7, 1-8. [CrossRef] [PubMed]

16. World Health Organization. Five Keys to Safer Food Manual Safer Food Manual; WHO: Geneva, Switzerland, 2006; Volume 6, pp. 154-196, ISBN 9241594632.

17. Londero, A.; Costa, M.; Galli, L.; Brusa, V.; Linares, L.; Prieto, M.; Leotta, G. Characterization and subtyping of Listeria monocytogenes strains from butcher shops. LWT Food Sci. Technol. 2019, 113, 1-6. [CrossRef]

18. Pérez-Rodríguez, F.; Valero, A.; Carrasco, E.; García, R.M.; Zurera, G. Understanding and modelling bacterial transfer to foods: A review. Food Sci. Technol. 2008, 19, 131-144. [CrossRef]

19. Finn, S.; Condell, O.; McClure, P.; Amézquita, A.; Fanning, S. Mechanisms of survival, responses, and sources of Salmonella in low-moisture environments. Front. Microbiol. 2013, 4, 1-15. [CrossRef]

20. EFSA-ECDC. The European Union summary report on trends and sources of zoonoses, zoonotic agents and food-borne outbreaks in 2010. EFSA J. 2012, 17, 1-442. [CrossRef]

21. Doijad, S.P.; Barbuddhe, S.B.; Garg, S.; Poharkar, K.V.; Kalorey, D.R.; Kurkure, N.V.; Rawool, D.B.; Chakraborty, T. Biofilm-forming abilities of Listeria monocytogenes serotypes isolated from different sources. PLoS ONE 2015, 10, e0137046. [CrossRef]

22. Melo, J.; Andrew, P.W.; Faleiro, M.L. Listeria monocytogenes in cheese and the dairy environment remains a food safety challenge: The role of stress responses. Food Res. Int. 2015, 67, 75-90. [CrossRef]

23. Møretrø, T.; Langsrud, S. Listeria monocytogenes: Biofilm formation and persistence in food-processing environments. Biofilms 2004, 1, 107-121. [CrossRef]

24. Magalhães, R.; Ferreira, V.; Brandão, T.R.S.; Palencia, R.C.; Almeida, G.; Teixeira, P. Persistent and non-persistent strains of Listeria monocytogenes: A focus on growth kinetics under different temperature, salt, and $\mathrm{pH}$ conditions and their sensitivity to sanitizers. Food Microbiol. 2016, 57, 103-108. [CrossRef] [PubMed]

25. Gaulin, C.; Ramsay, D.; Bekal, S. Widespread listeriosis outbreak attributable to pasteurized cheese, which led to extensive cross-contamination affecting cheese retailers, Quebec, Canada, 2008. J. Food Prot. 2012, 75, 71-78. [CrossRef] [PubMed]

26. Pagadala, S.; Parveen, S.; Rippen, T.; Luchansky, J.B.; Call, J.E.; Tamplin, M.L.; Porto-Fett, A.C.S. Prevalence, characterization and sources of Listeria monocytogenes in blue crab (Callinectus sapidus) meat and blue crab processing plants. Food Microbiol. 2012, 31, 263-270. [CrossRef] [PubMed]

27. McCollum, J.T.; Cronquist, A.B.; Silk, B.J.; Jackson, K.A.; O'Connor, K.A.; Cosgrove, S.; Gossack, J.P.; Parachini, S.S.; Jain, N.S.; Ettestad, P.; et al. Multistate outbreak of listeriosis associated with cantaloupe. N. Engl. J. Med. 2013, 369, 944-953. [CrossRef]

28. Multistate Outbreak of Listeriosis Linked to Blue Bell Creameries Products (Final Update) ICDC. Available online: https: / / twww.cdc.gov/listeria/outbreaks/ice-cream-03-15/index.html (accessed on 24 November 2020).

29. Spanu, C.; Scarano, C.; Ibba, M.; Spanu, V.; De Santis, E.P.L. Occurrence and traceability of Listeria monocytogenes strains isolated from sheep's milk cheese-making plants environment. Food Control 2015, 47, 318-325. [CrossRef]

30. Acciari, V.A.; Iannetti, L.; Gattuso, A.; Sonnessa, M.; Scavia, G.; Montagna, C.; Addante, N.; Torresi, M.; Zocchi, L.; Scattolini, S.; et al. Tracing sources of Listeria contamination in traditional Italian cheese associated with a US outbreak: Investigations in Italy. Epidemiol. Infect. 2016, 144, 2719-2727. [CrossRef]

31. Luo, L.; Zhang, Z.; Wang, H.; Wang, P.; Lan, R.; Deng, J.; Miao, Y.; Wang, Y.; Wang, Y.; Xu, J.; et al. A 12-month longitudinal study of Listeria monocytogenes contamination and persistence in pork retail markets in China. Food Control 2017, 76, 66-73. [CrossRef]

32. Li, H.; Wang, P.; Lan, R.; Luo, L.; Cao, X.; Wang, Y.; Wang, Y.; Li, H.; Zhang, L.; Ji, S.; et al. Risk factors and level of Listeria monocytogenes contamination of raw pork in retail markets in China. Front. Microbiol. 2018, 9, 1-10. [CrossRef]

33. Listeriosis-Spain /WHO. Available online: http://www.who.int/csr/don/16-september-2019-listeriosis-spain/en/ (accessed on 9 December 2020). 
34. Lüth, S.; Halbedel, S.; Rosner, B.; Wilking, H.; Holzer, A.; Roedel, A.; Dieckmann, R.; Vincze, S.; Prager, R.; Flieger, A.; et al. Backtracking and forward checking of human listeriosis clusters identified a multiclonal outbreak linked to Listeria monocytogenes in meat products of a single producer. Emerg. Microbes Infect. 2020, 9, 1600-1608. [CrossRef]

35. Carrasco, E.; Morales-Rueda, A.; García-Gimeno, R.M. Cross-contamination and recontamination by Salmonella in foods: A review. Food Res. Int. 2012, 45, 545-556. [CrossRef]

36. Ríos-Castillo, A.G.; Ripolles-Avila, C.; Rodriguez Jerez, J.J. Detection of Salmonella Typhimurium and Listeria monocytogenes biofilm cells exposed to different drying and pre-enrichment times using conventional and rapid methods. Int. J. Food Microbiol. 2020, 324, 1-9. [CrossRef] [PubMed]

37. Ríos-Castillo, A.G.; Ripolles-avila, C.; Rodríguez-Jerez, J.J. The Effects of dry, humid and wear conditions on the antimicrobial efficiency of triclosan-containing surfaces. Appl. Sci. 2019, 9, 1717. [CrossRef]

38. Fuster-Valls, N.; Hernández-Herrero, M.; Marín-de-Mateo, M.; Rodríguez-Jerez, J. Effect of different environmental conditions on the bacteria survival on stainless steel surfaces. Food Control 2008, 19, 308-314. [CrossRef]

39. Lee, B.H.; Cole, S.; Badel-Berchoux, S.; Guillier, L.; Felix, B.; Krezdorn, N.; Hébraud, M.; Bernardi, T.; Sultan, I.; Piveteau, P. Biofilm formation of Listeria monocytogenes strains under food processing environments and pan-genome-wide association study. Front. Microbiol. 2019, 10, 1-18. [CrossRef]

40. Ripolles-Avila, C.; Hascoët, A.S.; Guerrero-Navarro, A.E.; Rodríguez-Jerez, J.J. Establishment of incubation conditions to optimize the in vitro formation of mature Listeria monocytogenes biofilms on food-contact surfaces. Food Control 2018, 92, 240-248. [CrossRef]

41. Møretrø, T.; Langsrud, S.; Heir, E. Bacteria on meat abattoir process surfaces after sanitation: Characterisation of survival properties of Listeria monocytogenes and the commensal bacterial flora. Adv. Microbiol. 2013, 03, 255-264. [CrossRef]

42. Castro-Rosas, J.; Escartín, E.F. Increased tolerance of Vibrio cholerae $\mathrm{O} 1$ to temperature, $\mathrm{pH}$, or drying associated with colonization of shrimp carapaces. Int. J. Food Microbiol. 2005, 102, 195-201. [CrossRef]

43. Speranza, B.; Monacis, N.; Sinigaglia, M.; Corbo, M.R. Approaches to removal and killing of Salmonella spp. biofilms. J. Food Process. Preserv. 2016, 41, 1-9. [CrossRef]

44. Yin, W.; Wang, Y.; Liu, L.; He, J. Biofilms: The microbial "protective clothing" in extreme environments. Int. J. Mol. Sci. 2019, 20, 3423. [CrossRef]

45. Tribedi, P.; Sil, A.K. Cell surface hydrophobicity: A key component in the degradation of polyethylene succinate by Pseudomonas sp. AKS2. J. Appl. Microbiol. 2013, 116, 295-303. [CrossRef]

46. Stoodley, P.; Sauer, K.; Davies, D.G.; Costerton, J.W. Biofilms as complex differentiated communities. Annu. Rev. Microbiol. 2002, 56, 187-209. [CrossRef] [PubMed]

47. Kumar, C.G.; Anand, S.K. Significance of microbial biofilms in food industry: A review. Int. J. Food Microbiol. 1998, 42, 9-27. [CrossRef]

48. Chmielewski, R.A.N.; Frank, J.F. Biofilm formation and control in food processing facilities. Compr. Rev. Food Sci. Food Saf. 2003, 2, 22-32. [CrossRef]

49. Donlan, R.M. Biofilms: Microbial life on surfaces. Emerg. Infect. Dis. 2002, 8, 881-890. [CrossRef] [PubMed]

50. Flemming, H.C.; Neu, T.R.; Wozniak, D.J. The EPS matrix: The house of biofilm cells. Emerg. Infect. Dis. 2007, 189, 7945-7947. [CrossRef]

51. Bogino, P.C.; Oliva, M.; de las, M.; Sorroche, F.G.; Giordano, W. The role of bacterial biofilms and surface components in plant-bacterial associations. Int. J. Mol. Sci. 2013, 14, 15838-15859. [CrossRef]

52. Ripolles-avila, C.; Ramos-Rubio, M.; Hascoët, A.S.; Castillo, M.; Rodríguez-Jerez, J.J. New approach for the removal of mature biofilms formed by wild strains of Listeria monocytogenes isolated from food contact surfaces in an Iberian pig processing plant. Int. J. Food Microbiol. 2020, 323, 108595. [CrossRef]

53. Sauer, K.; Camper, A.K.; Ehrlich, G.D.; Costerton, J.W.; Davies, D.G. Pseudomonas aeruginosa displays multiple phenotypes during development as a biofilm. J. Bacteriol. 2002, 184, 1140-1154. [CrossRef]

54. Percival, S.L.; Knottenbelt, D.C.; Cochrane, C.A. Biofilms and Veterinary Medicine. En Springer Series on Biofilms; Springer International Publishing: Basel, Switzerland, 2011; pp. 1-39.

55. Todhanakasem, T.; Young, G.M. Loss of flagellum-based motility by Listeria monocytogenes results in formation of hyperbiofilms. J. Bacteriol. 2008, 190, 6030-6034. [CrossRef]

56. Gründling, A.; Burrack, L.S.; Bouwer, H.G.A.; Higgins, D.E. Listeria monocytogenes regulates flagellar motility gene expression through MogR, a transcriptional repressor required for virulence. Proc. Natl. Acad. Sci. USA 2004, 101, 12318-12323. [CrossRef]

57. Lemon, K.P.; Higgins, D.E.; Kolter, R. Flagellar motility is critical for Listeria monocytogenes biofilm formation. J. Bacteriol. 2007, 189, 4418-4424. [CrossRef] [PubMed]

58. Tresse, O.; Lebret, V.; Garmyn, D.; Dussurget, O. The impact of growth history and flagellation on the adhesion of various Listeria monocytogenes strains to polystyrene. Can. J. Microbiol. 2009, 55, 189-196. [CrossRef] [PubMed]

59. Tresse, O.; Shannon, K.; Pinon, A.; Malle, P.; Vialette, M.; Midelet-Bourdin, G. Variable adhesion of Listeria monocytogenes isolates from food-processing facilities and clinical cases to inert surfaces. J. Food Prot. 2007, 70, 1569-1578. [CrossRef] [PubMed]

60. Poimenidou, S.V.; Chrysadakou, M.; Tzakoniati, A.; Bikouli, V.C.; Nychas, G.J.; Skandamis, P.N. Variability of Listeria monocytogenes strains in biofilm formation on stainless steel and polystyrene materials and resistance to peracetic acid and quaternary ammonium compounds. Int. J. Food Microbiol. 2016, 237, 164-171. [CrossRef] 
61. Monk, I.R.; Cook, G.M.; Monk, B.C.; Bremer, P.J. Morphotypic conversion in Listeria monocytogenes biofilm formation: Biological significance of rough colony isolates. Appl. Environ. Microbiol. 2004, 70, 6686-6694. [CrossRef]

62. Colagiorgi, A.; Di Ciccio, P.; Zanardi, E.; Ghidini, S.; Ianieri, A. A look inside the Listeria monocytogenes biofilms extracellular matrix. Microorganisms 2016, 4, 22. [CrossRef]

63. Flemming, H.C.; Wingender, J. The biofilm matrix. Nat. Rev. Microbiol. 2010, 8, 623-633. [CrossRef]

64. Mazaheri, T.; Ripolles-Avila, C.; Hascoët, A.S.; Rodríguez-Jerez, J.J. Effect of an enzymatic treatment on the removal of mature Listeria monocytogenes biofilms: A quantitative and qualitative study. Food Control 2020, 114, 107266. [CrossRef]

65. Branda, S.S.; Vik, Å.; Friedman, L.; Kolter, R. Biofilms: The matrix revisited. Trends Microbiol. 2005, 13, 20-26. [CrossRef]

66. Ryder, C.; Byrd, M.; Wozniak, D.J. Role of polysaccharides in Pseudomonas aeruginosa biofilm development. Curr. Opin. Microbiol. 2007, 10, 644-648. [CrossRef]

67. Lasa, I.; Penadés, J.R. Bap: A family of surface proteins involved in biofilm formation. Res. Microbiol. 2006, 157, 99-107. [CrossRef] [PubMed]

68. Whitchurch, C.B.; Tolker-Nielsen, T.; Ragas, P.C.; Mattick, J.S. Extracellular DNA required for bacterial biofilm formation. Science 2002, 295, 1487. [CrossRef] [PubMed]

69. Combrouse, T.; Sadovskaya, I.; Faille, C.; Kol, O.; Guérardel, Y.; Midelet-Bourdin, G. Quantification of the extracellular matrix of the Listeria monocytogenes biofilms of different phylogenic lineages with optimization of culture conditions. J. Appl. Microbiol. 2013, 114, 1120-1131. [CrossRef] [PubMed]

70. Longhi, C.; Scoarughi, G.L.; Poggiali, F.; Cellini, A.; Carpentieri, A.; Seganti, L.; Pucci, P.; Amoresano, A.; Cocconcelli, P.S.; Artini, M.; et al. Protease treatment affects both invasion ability and biofilm formation in Listeria monocytogenes. Microb. Pathog 2008, 45, 45-52. [CrossRef]

71. Brauge, T.; Sadovskaya, I.; Faille, C.; Benezech, T.; Maes, E.; Guerardel, Y.; Midelet-Bourdin, G. Teichoic acid is the major polysaccharide present in the Listeria monocytogenes biofilm matrix. FEMS Microbiol. Lett. 2016, 363, 1-7. [CrossRef]

72. Tezel, U.; Pavlostathis, S.G. Quaternary ammonium disinfectants: Microbial adaptation, degradation and ecology. Curr. Opin. Biotechnol. 2015, 33, 296-304. [CrossRef]

73. Chambless, J.D.; Hunt, S.M.; Stewart, P.S. A three-dimensional computer model of four hypothetical mechanisms protecting biofilms from antimicrobials. Appl. Environ. Microbiol. 2006, 72, 2005-2013. [CrossRef]

74. Møretrø, T.; Langsrud, S. Residential bacteria on surfaces in the food industry and their implications for food safety and quality. Compr. Rev. Food Sci. Food Saf. 2017, 16, 1022-1041. [CrossRef]

75. Ferreira, V.; Wiedmann, M.; Teixeira, P.; Stasiewicz, M.J. Listeria monocytogenes persistence in food-associated environments: Epidemiology, strain characteristics, and implications for public health. J. Food Prot. 2014, 77, 150-170. [CrossRef]

76. Freitag, N.E.; Port, G.C.; Miner, M.D. Listeria monocytogenes-From saprophyte to intracellular pathogen. Nat. Rev. Microbiol. 2009, 7, 623-628. [CrossRef]

77. Buchanan, R.L.; Gorris, L.G.M.; Hayman, M.M.; Jackson, T.C.; Whiting, R.C. A review of Listeria monocytogenes: An update on outbreaks, virulence, dose-response, ecology, and risk assessments. Food Control 2017, 75, 1-13. [CrossRef]

78. Wilks, S.A.; Michels, H.T.; Keevil, C.W. Survival of Listeria monocytogenes Scott A on metal surfaces: Implications for crosscontamination. Int. J. Food Microbiol. 2006, 111, 93-98. [CrossRef] [PubMed]

79. Liu, D. Identification, subtyping and virulence determination of Listeria monocytogenes, an important foodborne pathogen. J. Med. Microbiol. 2006, 55, 645-659. [CrossRef] [PubMed]

80. Gandhi, M.; Chikindas, M.L. Listeria: A foodborne pathogen that knows how to survive. Int. J. Food Microbiol. 2007, 113, 1-15. [CrossRef] [PubMed]

81. Giaouris, E.; Heir, E.; Desvaux, M.; Hébraud, M.; Møretrø, T.; Langsrud, S.; Doulgeraki, A.; Nychas, G.J.; Kacániová, M.; Czaczyk, K.; et al. Intra-and inter-species interactions within biofilms of important foodborne bacterial pathogens. Front. Microbiol. 2015, 6, 1-26. [CrossRef]

82. Chenal-Francisque, V.; Lopez, J.; Cantinelli, T.; Caro, V.; Tran, C.; Leclercq, A.; Lecuit, M.; Brisse, S. World wide distribution of major clones of Listeria monocytogenes. Emerg. Infect. Dis. 2011, 17, 1110-1112. [CrossRef]

83. Orsi, R.H.; Bakker, H.C.; de Wiedmann, M. Listeria monocytogenes lineages: Genomics, evolution, ecology, and phenotypic characteristics. Int. J. Med. Microbiol. 2011, 301, 79-96. [CrossRef]

84. Dunn, K.A.; Bielawski, J.P.; Ward, T.J.; Urquhart, C.; Gu, H. Reconciling ecological and genomic divergence among lineages of Listeria under an "extended mosaic genome concept". Mol. Biol. Evol. 2009, 26, 2605-2615. [CrossRef]

85. Ortiz, S.; López, V.; Villatoro, D.; López, P.; Dávila, J.C.; Martínez-Suárez, J.V. A 3-year surveillance of the genetic diversity and persistence of Listeria monocytogenes in an Iberian pig slaughterhouse and processing plant. Foodborne Pathog. Dis. 2010, 7 , 1177-1184. [CrossRef]

86. Carpentier, B.; Cerf, O. Review-Persistence of Listeria monocytogenes in food industry equipment and premises. Int. J. Food Microbiol. 2011, 145, 1-8. [CrossRef]

87. Gómez, D.; Azón, E.; Marco, N.; Carramiñana, J.J.; Rota, C.; Ariño, A.; Yangüela, J. Antimicrobial resistance of Listeria monocytogenes and Listeria innocua from meat products and meat-processing environment. Food Microbiol. 2014, 42, 61-65. [CrossRef] [PubMed] 
88. Schlech, W.F.; Lavigne, P.M.; Bortolussi, R.A.; Allen, A.C.; Haldane, E.V.; Wort, A.J.; Hightower, A.W.; Johnson, S.E.; King, S.H.; Nicholls, E.S.; et al. Epidemic listeriosis-evidence for transmission by food. N. Engl. J. Med. 1983, 308, 203-206. [CrossRef] [PubMed]

89. Salama, P.J.; Embarek, P.K.B.; Bagaria, J.; Fall, I.S. Learning from Listeria: Safer food for all. Lancet 2018, 391, 2305-2306. [CrossRef]

90. EFSA-ECDC. The European Union summary report on trends and sources of zoonoses, zoonotic agents and food-borne outbreaks in 2017. EFSA J. 2018, 16, 1-276. [CrossRef]

91. Koutsoumanis, K.; Alvarez-Ordonez, A.; Bolton, D.; Bover-Cid, S.; Chemaly, M.; Davies, R.; De Cesare, A.; Herman, L.; Hilbert, F.; Lindqvist, R.; et al. The public health risk posed by Listeria monocytogenes in frozen fruit and vegetables including herbs, blanched during processing. EFSA J. 2020, 18, 1-102. [CrossRef]

92. Gelbíčová, T.; Zobaníková, M.; Tomáštíková, Z.; Van Walle, I.; Ruppitsch, W.; Karpíšková, R. An outbreak of listeriosis linked to turkey meat products in the Czech Republic, 2012-2016. Epidemiol. Infect. 2018, 146, 1407-1412. [CrossRef]

93. Colagiorgi, A.; Bruini, I.; Di Ciccio, P.A.; Zanardi, E.; Ghidini, S.; Ianieri, A. Listeria monocytogenes biofilms in the wonderland of food industry. Pathogens 2017, 6, 41. [CrossRef]

94. Cloete, T.E. Resistance mechanisms of bacteria to antimicrobial compounds. Int. Biodeterior. Biodegrad. 2003, 51, 277-282. [CrossRef]

95. Pan, Y.; Breidt, F., Jr.; Kathariou, S. Resistance of Listeria monocytogenes biofilms to sanitizing agents in a simulated food processing environment. Appl. Environ. Microbiol. 2006, 72, 7711-7717. [CrossRef]

96. Ripolles-Avila, C.; Cervantes-Huaman, B.H.; Hascoët, A.S.; Yuste, J.; Rodríguez-Jerez, J.J. Quantification of mature Listeria monocytogenes biofilm cells formed by an in vitro model: A comparison of different methods. Int. J. Food Microbiol. 2019, 289, 209-214. [CrossRef]

97. Chavant, P.; Martinie, B.; Meylheuc, T.; Bellon-Fontaine, M.N.; Hebraud, M. Listeria monocytogenes LO28: Surface physicochemical properties and ability to form biofilms at different temperatures and growth phases. Appl. Environ. Microbiol. 2002, 68, 728-737. [CrossRef] [PubMed]

98. Blackman, I.C.; Frank, J.F. Growth of Listeria monocytogenes as a biofilm on various food-processing surfaces. J. Food Prot. 1996, 59, 827-831. [CrossRef] [PubMed]

99. Borucki, M.K.; Peppin, J.D.; White, D.; Loge, F.; Call, D.R. Variation in biofilm formation among strains of Listeria monocytogenes. Appl. Environ. Microbiol. 2003, 69, 7336-7342. [CrossRef] [PubMed]

100. Renier, S.; Hébraud, M.; Desvaux, M. Molecular biology of surface colonization by Listeria monocytogenes: An additional facet of an opportunistic Gram-positive foodborne pathogen. Environ. Microbiol. 2011, 13, 835-850. [CrossRef]

101. Fraqueza, M.J.; Barreto, A.S. HACCP: Hazard Analysis and Critical Control Points. In Handbook of Fermented Meat and Poultry, 2nd ed.; Wiley Blackwell: Hoboken, NJ, USA, 2014; pp. 469-485, ISBN 9781118522653.

102. Holah, J.T.; BRI, C. UK Cleaning and Disinfection Practices in Food Processing; Woodhead Publishing Limited: Cambridge, UK, 2014; Volume 259, ISBN 9780857094292.

103. Guerrero-Navarro, A.E.; Ríos-Castillo, A.G.; Ripolles-Avila, C.; Hascoët, A.S.; Felipe, X.; Rodriguez Jerez, J.J. Development of a dairy fouling model to assess the efficacy of cleaning procedures using alkaline and enzymatic products. LWT Food Sci. Technol. 2019, 106, 44-49. [CrossRef]

104. Holah, J.; Childs, D. Cleaning and disinfection validation. In Reference Module in Food Science; Elsevier: Lancashire, UK, 2019; pp. 1-17, ISBN 9780081005965.

105. Hofmann, J.; Åkesson, S.; Curiel, G.; Wouters, P.; Timperley, A. Hygienic Design Principles; European Hygienic Engineering \& Design Group: Frankfurt, Germany, 2018; pp. 1-13.

106. Holah, J. Cleaning and disinfection objectives. In Reference Module in Food Science; Elsevier: Lancashire, UK, 2018. [CrossRef]

107. Simões, M.; Simões, L.C.; Machado, I.; Pereira, M.O.; Vieira, M.J. Control of flow-generated biofilms with surfactants: Evidence of resistance and recovery. Food Bioprod. Process. 2006, 84, 338-345. [CrossRef]

108. Troller, J.A. Sanitation in Food Processing; Academic Press: San Diego, CA, USA, 1993; ISBN 97801270065500127006559.

109. Fontecha Umaña, F. Estudio de la Eficacia Bactericida y Bacteriostática de Productos Quiímicos Embebidos en Materiales. Ph.D. Thesis, Universitat Autònoma de Barcelona, Department of Animal and Food Science, Barcelona, Spain, 2014.

110. Gram, L.; Bagge-Ravn, D.; Ng, Y.Y.; Gymoese, P.; Vogel, B.F. Influence of food soiling matrix on cleaning and disinfection efficiency on surface attached Listeria monocytogenes. Food Control 2007, 18, 1165-1171. [CrossRef]

111. Simões, M.; Simões, L.C.; Vieira, M.J. A review of current and emergent biofilm control strategies. LWT Food Sci. Technol. 2010, 43, 573-583. [CrossRef]

112. McEntire, J. Guidance on Environmental Monitoring and Control of Listeria for the Fresh Produce Industry. Available online: https: / / www.unitedfresh.org/guidance-on-environmental-monitoring-and-control-of-listeria-for-the-fresh-produceindustry-2nd-ed/ (accessed on 12 January 2021).

113. Pricope, L.; Nicolau, A.; Wagner, M.; Rychli, K. The effect of sublethal concentrations of benzalkonium chloride on invasiveness and intracellular proliferation of Listeria monocytogenes. Food Control 2013, 31, 230-235. [CrossRef]

114. Rodríguez-Melcón, C.; Capita, R.; Rodríguez-Jerez, J.J.; Martínez-Suárez, J.V.; Alonso-Calleja, C. Effect of low doses of disinfectants on the biofilm-forming ability of Listeria monocytogenes. Foodborne Pathog. Dis. 2019, 16, 262-268. [CrossRef]

115. Henriques, A.R.; Gama, L.T.; Fraqueza, M.J. Tracking Listeria monocytogenes contamination and virulence-associated characteristics in the ready-to-eat meat-based food products industry according to the hygiene level. Int. J. Food Microbiol. 2017, 242, 101-106. [CrossRef] [PubMed] 
116. Gabriel, A.A.; Ballesteros, M.L.P.; Rosario, L.M.D.; Tumlos, R.B.; Ramos, H.J. Elimination of Salmonella enterica on common stainless steel food contact surfaces using UV-C and atmospheric pressure plasma jet. Food Control 2018, 86, 90-100. [CrossRef]

117. Galié, S.; García-Gutiérrez, C.; Miguélez, E.M.; Villar, C.J.; Lombó, F. Biofilms in the food industry: Health aspects and control methods. Front. Microbiol. 2018, 9, 1-18. [CrossRef] [PubMed]

118. Guerrero-Navarro, A.E.; Ríos-Castillo, A.G.; Ripolles-Avila, C.; Felipe, X.; Rodríguez-Jerez, J.J. Microscopic analysis and microstructural characterization of the organic and inorganic components of dairy fouling during the cleaning process. J. Dairy Sci. 2020, 103, 2117-2127. [CrossRef] [PubMed]

119. Gutiérrez, D.; Rodríguez-Rubio, L.; Martínez, B.; Rodríguez, A.; García, P. Bacteriophages as weapons against bacterial biofilms in the food industry. Front. Microbiol. 2016, 7, 1-15. [CrossRef] [PubMed]

120. Parasion, S.; Kwiatek, M.; Gryko, R.; Mizak, L.; Malm, A. Bacteriophages as an alternative strategy for fighting biofilm development. Pol. J. Microbiol. 2014, 63, 137-145. [CrossRef]

121. Blana, V.A.; Lianou, A.; Nychas, G.J.E. Quorum sensing and microbial ecology of foods. In Quantitative Microbiology in Food Processing: Modeling the Microbial Ecology; Wiley Blackwell: Hoboken, NJ, USA, 2016; pp. 600-616, ISBN 9781118823071.

122. Coughlan, L.M.; Cotter, P.D.; Hill, C.; Alvarez-Ordóñez, A. New weapons to fight old enemies: Novel strategies for the (bio)control of bacterial biofilms in the food industry. Front. Microbiol. 2016, 7, 1-21. [CrossRef]

123. Ripolles-Avila, C.; Rodríguez-Jerez, J.J. Novel intervention techniques in the food industry. In Trends in Quorum Sensing and Quorum Quenching; CRC Press: Boca Raton, FL, USA, 2020; pp. 291-305.

124. Cui, H.; Zhang, C.; Li, C.; Lin, L. Antibacterial mechanism of oregano essential oil. Ind. Crops Prod. 2019, 139, 111498. [CrossRef]

125. Elhidar, N.; Nafis, A.; Kasrati, A.; Goehler, A.; Bohnert, J.A.; Abbad, A.; Hassani, L.; Mezrioui, N.E. Chemical composition, antimicrobial activities and synergistic effects of essential oil from Senecio anteuphorbium, a Moroccan endemic plant. Ind. Crops Prod. 2019, 130, 310-315. [CrossRef]

126. Hu, W.; Li, C.; Dai, J.; Cui, H.; Lin, L. Antibacterial activity and mechanism of Litsea cubeba essential oil against methicillin-resistant Staphylococcus aureus (MRSA). Ind. Crops Prod. 2019, 130, 34-41. [CrossRef]

127. Hascoët, A.S.; Ripolles-Avila, C.; Guerrero-Navarro, A.E.; Rodríguez-Jerez, J.J. Microbial ecology evaluation of an Iberian pig processing plant through implementing SCH sensors and the influence of the resident microbiota on Listeria monocytogenes. Appl. Sci. 2019, 9, 4611. [CrossRef]

128. Nguyen, U.T.; Burrows, L.L. DNase I and proteinase K impair Listeria monocytogenes biofilm formation and induce dispersal of pre-existing biofilms. Int. J. Food Microbiol. 2014, 187, 26-32. [CrossRef] [PubMed]

129. Montañez-Izquierdo, V.Y.; Salas-Vázquez, D.I.; Rodríguez-Jerez, J.J. Use of epifluorescence microscopy to assess the effectiveness of phage P100 in controlling Listeria monocytogenes biofilms on stainless steel surfaces. Food Control 2012, 23, 470-477. [CrossRef]

130. Gao, Z.; Zhong, W.; Chen, K.; Tang, P.; Guo, J. Chemical composition and anti-biofilm activity of essential oil from Citrus medica L. var. sarcodactylis Swingle against Listeria monocytogenes. Ind. Crops Prod. 2020, 144, 1-8. [CrossRef]

131. McIntyre, L.; Wilcott, L.; Naus, M. Listeriosis outbreaks in British Columbia, Canada, caused by soft ripened cheese contaminated from environmental sources. BioMed Res. Int. 2015, 2015, 18-20. [CrossRef]

132. Aspri, M.; Field, D.; Cotter, P.D.; Ross, P.; Hill, C.; Papademas, P. Application of bacteriocin-producing Enterococcus faecium isolated from donkey milk, in the bio-control of Listeria monocytogenes in fresh whey cheese. Int. Dairy J. 2017, 73, 1-9. [CrossRef]

133. Ramaswamy, V.; Cresence, V.M.; Rejitha, J.S.; Lekshmi, M.U.; Dharsana, K.S.; Prasad, S.P.; Vijila, H.M. Listeria—Review of epidemiology and pathogenesis. J. Microbiol. 2007, 40, 4-13.

134. Mucchetti, G.; Bonvini, B.; Francolino, S.; Neviani, E.; Carminati, D. Effect of washing with a high pressure water spray on removal of Listeria innocua from Gorgonzola cheese rind. Food Control 2008, 19, 521-525. [CrossRef]

135. Morandi, S.; Brasca, M.; Lodi, R.; Battelli, G. Impiego di ozono per il controllo di Listeria monocytogenes in diverse tipologie di formaggio. Scienza e Tecnica Lattiero-Casearia 2009, 60, 211-215.

136. Bernini, V.; Dalzini, E.; Lazzi, C.; Bottari, B.; Bisotti, S.; Fontana, M.; Neviani, E. A multi-sampling approach to evaluate an infrared surface treatment for reducing Listeria monocytogenes contamination on whole gorgonzola cheese rinds. Food Control 2015, 55, 75-81. [CrossRef]

137. Silva, C.C.; Silva, S.P.; Ribeiro, S.C. Application of bacteriocins and protective cultures in dairy food preservation. Front. Microbiol. 2018, 9, 1-15. [CrossRef] [PubMed]

138. Holah, J.T.; Taylor, J.H.; Dawson, D.J.; Hall, K.E. Biocide use in the food industry and the disinfectant resistance of persistent strains of Listeria monocytogenes and Escherichia coli. J. Appl. Microbiol. Symp. Suppl. 2002, 92, 111-120. [CrossRef]

139. Rodríguez-López, P.; Cabo, M.L. Tolerance development in Listeria monocytogenes-Escherichia coli dual-species biofilms after sublethal exposures to pronase-benzalkonium chloride combined treatments. Food Microbiol. 2017, 67, 58-66. [CrossRef] [PubMed]

140. Fallah, A.A.; Saei-Dehkordi, S.S.; Rahnama, M.; Tahmasby, H.; Mahzounieh, M. Prevalence and antimicrobial resistance patterns of Listeria species isolated from poultry products marketed in Iran. Food Control 2012, 28, 327-332. [CrossRef]

141. Gohar, S.; Abbas, G.; Sajid, S.; Sarfraz, M.; Ali, S.; Ashraf, M.; Aslam, R.; Yaseen, K. Prevalence and antimicrobial resistance of Listeria monocytogenes isolated from raw milk and dairy products. Matrix Sci. Med. 2017, 1, 10-14. [CrossRef]

142. Hellström, S. Contamination Routes and Control of Listeria monocytogenes in Food Production. Ph.D. Thesis, University of Helsinki, Helsinki, Finland, 2011. 
143. Fagerlund, A.; Moretro, T.; Heir, E.; Briandet, R.; Langsrud, S.; Møretrø, T.; Heir, E.; Briandet, R.; Langsruda, S. Cleaning and disinfection of biofilms composed of Listeria monocytogenes and background microbiota from meat processing surfaces. Appl. Environ. Microbiol. 2017, 83, 1-21. [CrossRef]

144. EFSA-ECDC. Multi-country outbreak of Listeria monocytogenes sequence type 6 infections linked to ready-to-eatmeat products-25 November 2019. EFSA J. 2019, 16, 1-15. [CrossRef]

145. Kleter, G.A. Control and Prevention of Contamination and Spoilage in the Traditional Production of Smoked Fish in Ghana; RIKILTVeiligheid \& Gezondheid: Wageningen, The Netherlands, 2004; pp. 1-23.

146. Shikongo-Nambabi, M.N.N.N.; Shoolongela, A.; Schneider, M. Control of bacterial contamination during marine fish processing. J. Biol. Life Sci. 2011, 3, 1-17. [CrossRef]

147. Tatterson, I.N.; Windsor, M.L. Torry Advisory Note No. 45 (Revised) Cleaning in the Fish Industry. Available online: http: / / www.fao.org/3/x5922e/x5922e00.htm\#Contents (accessed on 15 May 2020).

148. Wekell, M.M.; Manger, R.; Colburn, K.; Adams, A.; Hill, W. Microbiological quality of seafoods: Viruses, bacteria and parasites. In Seafoods: Chemistry, Processing Technology and Quality; Springer US: New York, NY, USA, 1994; pp. 196-219.

149. Holck, A.; Liland, K.H.; Carlehög, M.; Heir, E. Reductions of Listeria monocytogenes on cold-smoked and raw salmon fillets by UV-C and pulsed UV light. Innov. Food Sci. Emerg. Technol. 2018, 50, 1-10. [CrossRef]

150. Mcleod, A.; Hovde Liland, K.; Haugen, J.E.; Sørheim, O.; Myhrer, K.S.; Holck, A.L. Chicken fillets subjected to UV-C and pulsed UV light: Reduction of pathogenic and spoilage bacteria, and changes in sensory quality. J. Food Saf. 2018, 38, 1-15. [CrossRef]

151. Brauge, T.; Faille, C.; Leleu, G.; Denis, C.; Hanin, A.; Midelet, G. Treatment with disinfectants may induce an increase in viable but non culturable populations of Listeria monocytogenes in biofilms formed in smoked salmon processing environments. Food Microbiol. 2020, 92, 1-6. [CrossRef] [PubMed]

152. Duong, N.T.H. The Sanitising Efficiency of Different Disinfectants used in the Fish Industry; University of Fisheries: Karela, India, 2005.

153. Lasagabaster, A.; Jiménez, E.; Lehnherr, T.; Miranda-Cadena, K.; Lehnherr, H. Bacteriophage biocontrol to fight Listeria outbreaks in seafood. Food Chem. Toxicol. 2020, 145, 1-12. [CrossRef] [PubMed]

154. Sadekuzzaman, M.; Yang, S.; Mizan, M.F.R.; Kim, H.S.; Ha, S. Effectiveness of a phage cocktail as a biocontrol agent against L. monocytogenes biofilms. Food Control 2017, 78, 256-263. [CrossRef]

155. De Roever, C. Microbiological safety evaluations and recommendations on fresh produce. Food Control 1998, 9, 321-347. [CrossRef]

156. Soumet, C.; Ragimbeau, C.; Maris, P. Screening of benzalkonium chloride resistance in Listeria monocytogenes strains isolated during cold smoked fish production. Lett. Appl. Microbiol. 2005, 41, 291-296. [CrossRef]

157. Popowska, M.; Olszak, M.; Markiewicz, Z. Susceptibility of Listeria monocytogenes strains isolated from dairy products and frozen vegetables to antibiotics inhibiting murein synthesis and to disinfectants. Pol. J. Microbiol. 2006, 55, $279-288$.

158. Contamination Patterns of Listeria monocytogenes in a Frozen-Vegetable Processing Plant. Available online: http:/ /ovidsp.ovid. com/ovidweb.cgi?T=JS\&PAGE=reference\&D=fsta2\&NEWS=N\&AN=2016-04-Jh3428 (accessed on 9 December 2020).

159. Quantitative Assessment of Relative Risk to Public Health from Foodborne Listeria monocytogenes among Selected Categories of Ready-to-Eat Foods I FDA. Available online: https: / / www.fda.gov/food/cfsan-risk-safety-assessments / quantitative-assessmentrelative-risk-public-health-foodborne-listeria-monocytogenes-among-selected (accessed on 9 December 2020).

160. Pouillot, R.; Hoelzer, K.; Chen, Y.; Dennis, S.B. Listeria monocytogenes dose response revisited-Incorporating adjustments for variability in strain virulence and host susceptibility. Soc. Risk Anal. 2015, 35, 90-108. [CrossRef]

161. Cossu, F.; Spanu, C.; Deidda, S.; Mura, E.; Casti, D.; Pala, C.; Lamon, S.; Spanu, V.; Ibba, M.; Marrocu, E.; et al. Listeria spp. and Listeria monocytogenes contamination in ready-to-eat sandwiches collected from vending machines. Ital. J. Food Saf. 2016, 5, 61-64. [CrossRef]

162. Draft Guidance for Industry: Control of Listeria monocytogenes in Ready-to-Eat Foods I FDA. Available online: https://www. fda.gov/regulatory-information/search-fda-guidance-documents/draft-guidance-industry-control-listeria-monocytogenesready-eat-foods (accessed on 9 December 2020).

163. Liewen, M.B.; Marth, E.H. Growth and inhibition of microorganisms in the presence of sorbic acid: A review. J. Food Prot. 1985, 48, 364-375. [CrossRef]

164. Tassou, C.C.; Samaras, F.J.; Arkoudelos, J.S.; Mallidis, C.G. Survival of acid-adapted or non-adapted Salmonella Enteritidis, Listeria monocytogenes and Escherichia coli O157: H7, in traditional Greek salads. Int. J. Food Sci. Technol. 2009, 279-287. [CrossRef]

165. Vermeulen, A.; Smigic, N.; Rajkovic, A.; Gysemans, K.; Bernaerts, K.; Geeraerd, A.; Impe, J.V.A.N.; Debevere, J.; Devlieghere, F. Performance of a growth-no growth model for Listeria monocytogenes developed for mayonnaise-based salads: Influence of strain variability, food matrix, inoculation level, and presence of sorbic and benzoic acid. J. Food Prot. 2007, 70, $2118-2126$. [CrossRef] [PubMed]

166. Guidelines for Conducting Listeria monocytogenes Challenge Testing of Foods I FAO. Available online: https: / / agris.fao.org/ agris-search/search.do?recordID=US201301047377 (accessed on 3 May 2020).

167. Mitigation of Listeria monocytogenes in Ready-to-Eat Meats Using Lactic Acid Bacteria. Food Safety Magazine. Available online: https: //www.foodsafetymagazine.com/magazine-archive1/december-2016january-2017/mitigation-of-ilisteria-monocytogenesiin-ready-to-eat-meats-using-lactic-acid-bacteria / (accessed on 8 December 2020). 
168. Gall, K.; Scott, V.N.; Collette, R.; Jahncke, M.; Hicks, D.; Wiedmann, M. Implementing targeted good manufacturing practices and sanitation procedures to minimize Listeria contamination of smoked seafood products. Food Prot. Trends 2004, 24, 302-315.

169. Evaluation of Vinegar against Listeria monocytogenes in Ready-to-Eat (RTE) Deli Ham Stored at 4 Degrees. J. Food Prot. 2015, 78

(Suppl. A), 267. Available online: http:/ / ovidsp.ovid.com/ovidweb.cgi?T=JS\&PAGE=reference\&D=fsta2\&NEWS=N\&AN=2016 -04-Sj1594 (accessed on 12 January 2021). 